\title{
Assessment of the pozzolanic activity of ornamental stone waste after heat treatment and its effect on the mechanical properties of concretes
}

\section{Análise da caracterização pozolânica do resíduo de rochas ornamentais tratado termicamente e seu efeito nas propriedades mecânicas de concretos}
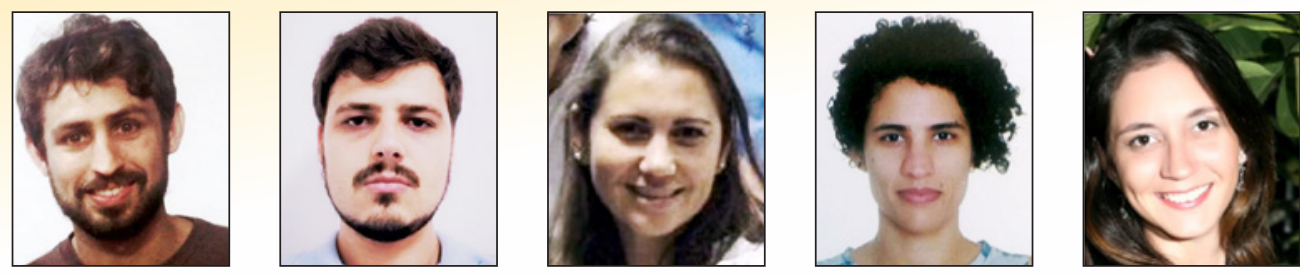

S. H. M. MITTRI a sergio-mittri@hotmail.com

M. K. DEGEN a maxdegen@hotmail.com

G. L. VIEIRA a geilma.vieira@gmail.com

J. S. VAZZOLER a janaina.vazzoler@gmail.com

L. H. C. H. RODRIGUES a laricarnielli@hotmail.com

\section{Abstract}

This paper aims at evaluating the pozzolanic properties of ornamental stone processing waste after heat treatment at $1200{ }^{\circ} \mathrm{C}(\mathrm{HTOSPW})$ and analyzing the influence on the mechanical strength of concrete produced with HTOSPW addition at the contents of $5 \%$ and $10 \%$ by mass of Portland cement. The HTOSPW shows promising results regarding the pozzolanic activity, revealing chemical and physical characteristics typical of pozzolanic materials in addition to being approved in the pozzolanicity tests performed. As for the concretes produced with HTOSPW addition, a significant increase in mechanical strength was observed, especially for concretes with a $10 \%$ addition.

Keywords: pozzolan, pozzolanic activity, ornamental stone waste, mechanical strength, heat treatment.

\section{Resumo}

O presente trabalho avalia as propriedades pozolânicas do resíduo do beneficiamento de rochas ornamentais tratado termicamente a $1200^{\circ} \mathrm{C}$ (RBROTT), além de analisar a influência desse material na resistência mecânica de concretos produzidos com $5 \%$ e $10 \%$ de adição em relação à massa de cimento. Quanto à atividade pozolânica, o RBROTT se mostrou promissor, tendo apresentado características químicas e físicas típicas de materiais pozolânicos, além de ser aprovado nos ensaios de pozolanicidade realizados. Quanto aos concretos produzidos com adição do RBROTT, observou-se um aumento significativo da resistência mecânica, principalmente para os concretos com $10 \%$ de adição.

Palavras-chave: pozolana, atividade pozolânica, resíduo de rochas ornamentais, resistência mecânica, tratamento térmico. 


\section{Introduction}

Raw material extraction and its processing generate wastes that generally are environmental liabilities. Aiming at solving this issue, many studies have presented the incorporation into materials of different wastes, which otherwise would be landfilled, giving them economical value and applicability in different areas of the civil construction sector. Among these wastes, the use of fly ash [1-5] and silica fume [6-10] can be highlighted; as these are used consistently worldwide in cementitious matrixes. They are applied as pozzolans, which react chemically with alkaline compounds produced during the hydration of cement, producing calcium silicate hydrate. Due to this fact, when applied in adequate proportions, pozzolans are capable of improving certain properties of the cementitious matrix of mortars and concretes.

A material that has been studied by different authors, regarding its use in cementitious [11-14], ceramic [15-18] and bituminous [1921] matrixes, is the ornamental stone processing waste (OSPW). In 2013, the worldwide production of ornamental stones was 123.5 Mt [22]. From its extraction to trading the amount of waste produced can be up to $40 \%$ of the total volume of stone extracted [17], and the amount of waste generated in the processing stage alone (cutting and polishing) can be 20 to $25 \%$ of the total volume of the stone block [17], or even reaching up to $30 \%$ [23]. As the OSPW is a chemically inert material, when applied to cementitious matrixes, it acts producing a pore-filling effect, known as the filler effect. Furthermore, it has a crystalline and inert structure, not able to react chemically with the other cement compounds. However, this material can have its crystalline structure modified after heat treatment in high temperatures, as it is the case of some known pozzolans on the market. To this moment, few studies have used heat treatment in this waste [24-26].

Aiming at improving the material properties, converting it into a potential pozzolan, this study performed a heat treatment on the OSPW at $1200^{\circ} \mathrm{C}$, producing the heat treated ornamental stone processing waste (HTOSPW). It is expected that the material presents an amorphous form and that it reacts with the resulting compounds of the cement hydration, in a process known as pozzolanic reaction.

\section{Materials and experimental program}

\subsection{Production and characterization of HTOSPW}

The HTOSPW was kiln dried at $100 \pm 5^{\circ} \mathrm{C}$ for humidity removal; thereafter, it was subjected to heat treatment, which consisted in gradually heating the waste in a gypsum container (Figure 1) until reaching $1200^{\circ} \mathrm{C}$, remaining at this temperature for $2 \mathrm{~h}$. Due to the heat treatment, the waste coalesced into a solid with vitreous appearance, as can be seen in Figure 1. The temperature of $1200^{\circ} \mathrm{C}$ was determined from the study of Uliana et al. [26], in which the temperatures of $1200{ }^{\circ} \mathrm{C}, 1300{ }^{\circ} \mathrm{C}, 1400{ }^{\circ} \mathrm{C}$ and $1500{ }^{\circ} \mathrm{C}$ were used. The authors assessed the temperatures influence in the feasibility of applying the heat treatment, in the resulting material mineralogy and pozzolanic activity as assessed by the method of Luxán [27]. Aiming at meet the fineness criterion for pozzolanic material as defined in NBR 12653 [28], the material was milled in a vibratory disc mill (Figure 1) for the time required to reach the

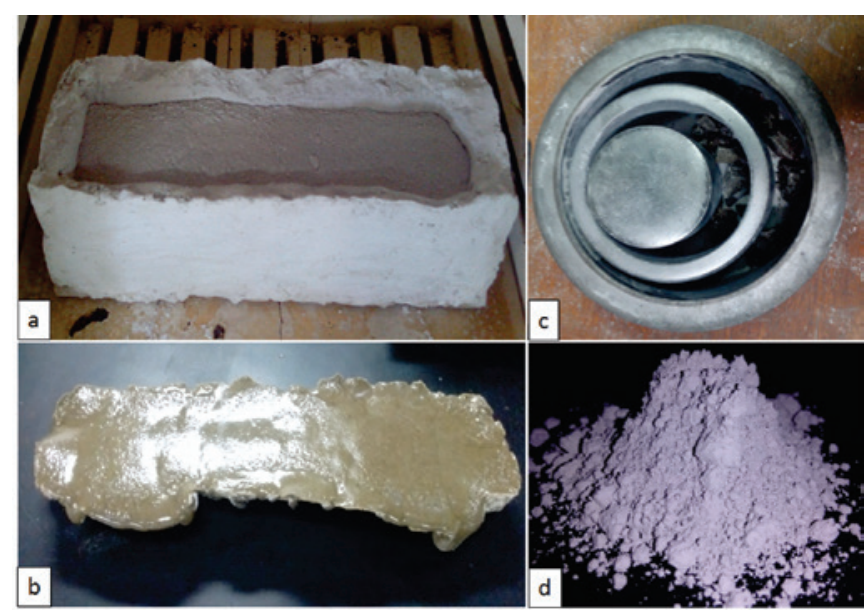

\section{Figure 1}

(a) Gypsum container with OSPW before heat treatment, (b) OSPW after heat treatment,

(c) Vibratory disc mill, (d) Heat treated waste after milling (HTOSPW)

maximum percentage of $20 \%$ of material retained on sieve $45 \mu \mathrm{m}$. After the milling process, the material presented a light grey colour, as can be seen in Figure 1.

After the HTOSPW production, it was performed its physical, chemical, mineralogical and microstructural characterizations. The physical characterization was done according to the procedures described in the NBR 15894 [29] and NBR 11579 [30], in order to assess the percentage of retained material in the sieves $45 \mu \mathrm{m}$ and $75 \mu \mathrm{m}$, indicating the material fineness. Additionally, in relation to the fineness, it was performed the test to determine the Blaine specific surface area. Still related to the physical characterization, it was determined the grain size distribution of the HTOSPW by using the laser particle size analyzer.

The chemical characterization of the HTOSPW was performed by the X-ray fluorescence test, whereas the mineralogical and microstructural characterizations were assessed by the X-ray diffraction and scanning electron microscope (SEM), respectively.

The physical, chemical and mineralogical characterizations are fundamental to evaluate if the HTOSPW presents the basic characteristics of a pozzolanic material, characterized by being a fine material, with a siliceous or silico-aluminous chemical composition presenting the majority of its structure in a vitreous (amorphous) form, with its small quantity of crystalline structure in the form of quartz and $\mathrm{C}_{3} \mathrm{~A}$ [31]. Nevertheless, it is also necessary to demonstrate its pozzolanic activity by assessing the waste capacity of reacting chemically with the calcium hydroxide $-\mathrm{Ca}(\mathrm{OH})_{2}$.

The first analysis performed to assess the pozzolanic activity of the HTOSPW was the test as according to Luxán et al. [27]. Initially, a conductivity measurement in a solution with only calcium hydroxide was carried out. After this initial measurement, the pozzolanic material was added to the solution, reacting with the free ions, thus, diminishing the electrical conductivity of the solution. After the time of $120 \mathrm{~s}$, it was performed the second measurement of conductivity. From its variation, it is possible to assess the level 
Table 1

Pozzolanic activity classification according to the method of Luxán

\begin{tabular}{cc}
\hline Material classification & $\begin{array}{c}\text { Conductivity variation }-\Delta \mathbf{c} \\
(\mathbf{m S} / \mathbf{c m})\end{array}$ \\
\hline Non pozzolanic & Lower than 0.4 \\
Variable pozzolanicity & Between 0.4 and 1.2 \\
Good pozzolanicity & Higher than 1.2 \\
\hline
\end{tabular}

of pozzolanic activity of the material, which depends of its capacity in reacting with the free ions. According to the test authors [27], the material should be classified in function of the conductivity variation, as according to Table 1.

As a comparative effect, it was performed the method of Luxán [27] in three different materials: OSPW, HTOSPW and metakaolin. It was decided to use metakaolin as it is a material of proven pozzolanicity, serving as a parameter for comparison.

NBR 12653 [28] established the minimum performance requirements for a material be classified as a pozzolan. The criteria are based in the performance of mortars using the potential pozzolanic material. The first assessment is done as according to NBR 5751 [32], which defines the procedures to determine the pozzolan performance when applied to produce a lime mortar $-\mathrm{Ca}(\mathrm{OH})_{2}$. The other test is done as according to NBR 5752 [33] test, which defines the procedures to determine the pozzolan performance index when applied to produce a cement mortar.

\subsection{Concrete mixtures proportions and production}

The cement used for the production of the mixtures was the high early-strength Portland cement (CPV-ARI), since it is the commercially available cement in the market with the lowest percentage of additions (addition can interfere with the test results if present in high proportion). The physical and chemical characteristics of the cement can be seen in Table 2. Natural white quartz sand and granitic coarse aggregate (No.1) were also used in the mixtures. Proportioning followed the procedures of the IPT/ EPUSP method of Helene and Terzian [34]. From this method, concrete mixtures were produced with 0,5 and $10 \%$ addition of HTOSPW by cement mass. Additionally, different water/cement (w/c) ratios were used: 0.4 and 0.6 . The mixtures proportions can be seen in Table 3.

The filler addition in an adequate proportion would be sufficient
Table 2

Chemical and physical composition of OSPW, HTOSPW and CP V-ARI cement

\begin{tabular}{|c|c|c|c|}
\hline $\begin{array}{l}\text { Chemical } \\
\text { composition }\end{array}$ & OSPW* & HTOSPW & CPV-ARI \\
\hline $\mathrm{SiO}_{2}$ & 66.82 & 67.11 & 19.42 \\
\hline $\mathrm{Al}_{2} \mathrm{O}_{3}$ & 13.50 & 23.42 & 4.87 \\
\hline $\mathrm{K}_{2}^{2} \mathrm{O}^{3}$ & 3.83 & 3.36 & 0.8 \\
\hline $\mathrm{CaO}$ & 3.44 & 2.62 & 63.69 \\
\hline $\mathrm{Fe}_{2} \mathrm{O}_{3}$ & 3.79 & 1.53 & 2.93 \\
\hline $\mathrm{MgO}$ & 0.93 & 1.5 & 0.86 \\
\hline $\mathrm{TiO}_{2}$ & 0.16 & 0.18 & - \\
\hline $\mathrm{SO}_{3}^{2}$ & 0.06 & 0.05 & 3.02 \\
\hline $\mathrm{P}_{2} \mathrm{O}_{5}$ & - & 0.05 & - \\
\hline $\mathrm{MnO}$ & - & 0.03 & - \\
\hline $\mathrm{Cr}_{2} \mathrm{O}_{3}$ & - & 0.01 & - \\
\hline $\mathrm{CO}_{2}$ & - & - & 2.49 \\
\hline $\mathrm{Rb}_{2} \mathrm{O}^{2}$ & - & 0.01 & - \\
\hline $\mathrm{ZrO}_{2}$ & - & 0.01 & - \\
\hline $\mathrm{CuO}$ & - & 0.01 & - \\
\hline $\mathrm{SrO}$ & - & 0.01 & - \\
\hline C & 1.11 & - & - \\
\hline L.O.I. & 3.50 & 0.1 & 0.78 \\
\hline $\begin{array}{c}\text { Physical } \\
\text { characteristics }\end{array}$ & OSPW & HTOSPW & CPV-ARI \\
\hline Density $\left(\mathrm{g} / \mathrm{cm}^{3}\right)$ & 2.53 & 2.45 & 3.09 \\
\hline $\begin{array}{c}\text { Blaine specific surface } \\
\text { area }\left(\mathrm{cm}^{2} / \mathrm{g}\right)\end{array}$ & 6179 & 6890 & 4751 \\
\hline $\begin{array}{l}\text { Retained on sieve } \\
\# 200\end{array}$ & 3.08 & 1.16 & - \\
\hline $\begin{array}{l}\text { Retained on sieve } \\
\# 325\end{array}$ & 7.00 & 9.57 & - \\
\hline $\begin{array}{l}\text { Retained on sieve } \\
\quad \# 400\end{array}$ & - & - & 2.2 \\
\hline * From Uliana et al. [26] & & & \\
\hline
\end{tabular}

to improve the mechanical strength of the concrete. Soares [35] and Dietrich [36] verified that the concrete mixtures produced with the addition of OSPW presented an increase in the mechanical strength with the content of $5 \%$, whereas with the contents of 10 and $15 \%$, it was noted a decrease. Conversely, Degen et al. [37] showed that the cement replacement by OSPW, without heat treatment, in the contents of 5,10 and $15 \%$ by cement mass reduced the mechanical strength of the analysed concretes. Based in these

\section{Table 3}

Concrete mixtures

\begin{tabular}{|c|c|c|c|c|c|c|}
\hline$w / c$ ratio & $\begin{array}{c}\text { Addition } \\
\text { content (\%) }\end{array}$ & Cement & HTOSPW & Sand & Gravel & $\begin{array}{c}\text { Cement } \\
\text { consumption } \\
\left(\mathrm{kg} / \mathrm{m}^{3}\right)\end{array}$ \\
\hline 0.4 & \multirow{2}{*}{$0 \%$} & \multirow{2}{*}{1} & - & 1.31 & 2.22 & 499.20 \\
\hline 0.6 & & & - & 2.89 & 3.74 & 296.03 \\
\hline 0.4 & \multirow{2}{*}{$5 \%$} & \multirow{2}{*}{1} & 0.05 & 1.31 & 2.22 & 488.27 \\
\hline 0.6 & & & 0.05 & 2.89 & 3.74 & 294.09 \\
\hline 0.4 & \multirow{2}{*}{$10 \%$} & \multirow{2}{*}{1} & 0.1 & 1.31 & 2.22 & 488.11 \\
\hline 0.6 & & & 0.1 & 2.89 & 3.74 & 292.82 \\
\hline
\end{tabular}




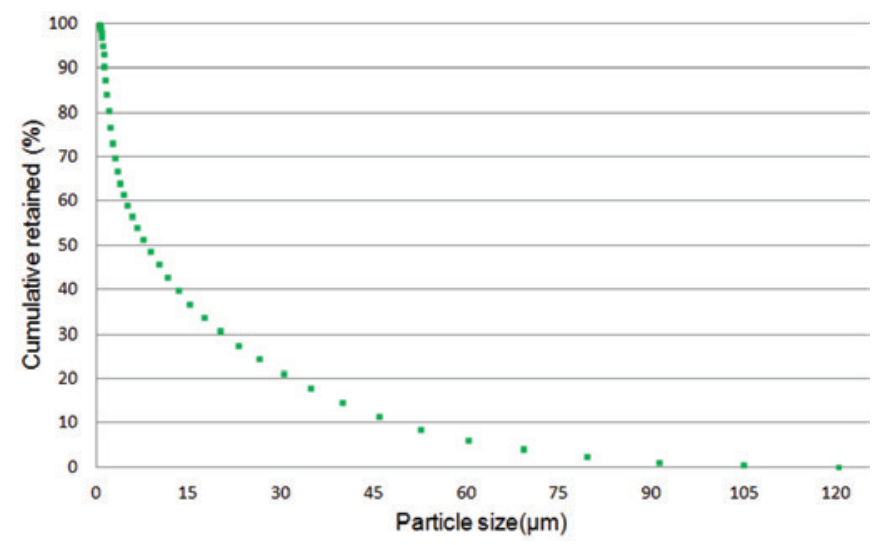

Figure 2

Particle size distribution of HTOSPW

studies, it was adopted the addition contents of 5 and $10 \%$ of HTOSPW by cement mass. The content of $10 \%$ addition of OSPW without treatment reduced the mechanical strength [35, 36]; thus, being pertinent to evaluate the influence at the same addition level with the waste after heat treatment.

In the fresh state, the concretes were evaluated by the slump test, established by the NBR NM 67 [38]. After this test, 15 cylindrical specimens of $100 \times 200 \mathrm{~mm}$ were prepared for each of the six mixtures analysed. The specimens were cured submerged in limesaturated water, being tested at 28,56 and 91 days.

\section{Results and discussion}

\subsection{HTOSPW characterization}

Regarding the fineness, the waste presented $9.57 \%$ of retained material on sieve $45 \mu \mathrm{m}$, and $1.16 \%$ of retained material on sieve $75 \mu \mathrm{m}$. NBR 12653 [28] establishes as a fineness criterion for the pozzolans the maximum of $20 \%$ retained on sieve $45 \mu \mathrm{m}$; thus, the HTOSPW met the fineness condition. Its Blaine value was $6870 \mathrm{~cm}^{2} / \mathrm{g}$, being a value higher than the commonly found for fly ash in several stud-

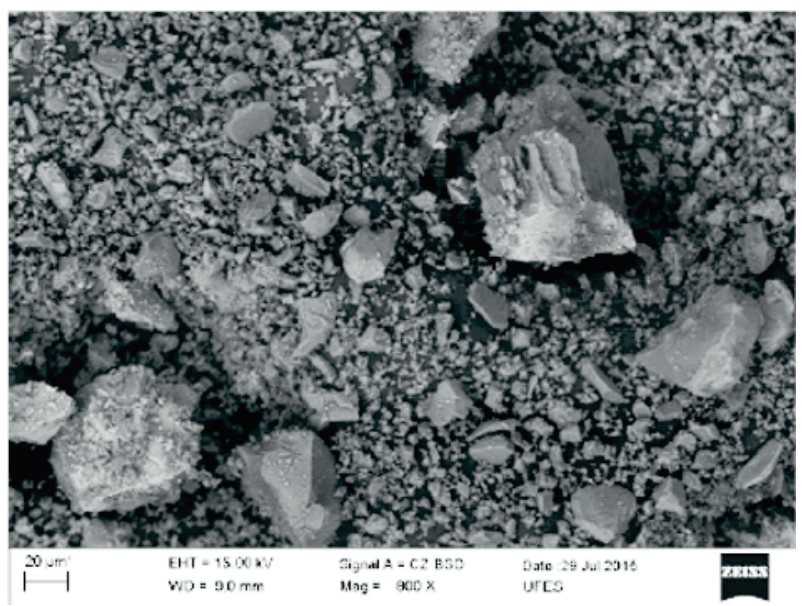

Figure 3

SEM image of HTOSPW at 800x magnification ies [39-41], nevertheless, inferior to the fineness of the silica fume, which can present values higher than $10000 \mathrm{~cm}^{2} / \mathrm{g}[6,42]$.

To evaluate the grain size distribution, it was used the laser particle size analyzer, obtaining the results presented in Figure 2. From this test, it was also obtained the values of D90 and D50, being 48.99 and $8.17 \mu \mathrm{m}$, respectively. It is possible to compare these results with the ones from retained in the sieves. As shown previously, the retained material in sieve 45 and $75 \mu \mathrm{m}$ were 9.57 and $1.16 \%$, respectively. In Figure 2, it is observed that the percentage of retained material in the sizes of 45 and $75 \mu \mathrm{m}$ are 11.83 and $3.12 \%$, respectively. Thus, it can be concluded that both values, from sieve analysis and the laser particle size analyzer, present similar results.

As for the particles shape, in Figure 3 it can be observed the image obtained by the SEM, identifying that the HTOSPW present the particles of varied dimensions. Furthermore, it is noted that the HTOSPW particles do not present a defined form, being angular and with sizes varying from 0.2 to $70 \mu \mathrm{m}$.

The level of amorphous phase of the HTOSPW was assessed through the X-ray diffraction test, with the results presented in Figure 4.

It can be seen in Figure 4 the presence of an amorphous halo between the ranges of $15^{\circ}$ and $40^{\circ}$, presenting a mixture of phases, that is, a certain degree of amorphism. In this figure, it is also possible to note the presence of peaks representing the crystalline phase of the quartz $\left(\mathrm{SiO}_{2}\right)$. The quartz crystals were not broken at the heat treatment at $1200{ }^{\circ} \mathrm{C}$ due to the fact that the melting temperature of this compound is higher than $1600^{\circ} \mathrm{C}$ [43]. Other studies have also identified the presence of quartz crystals when analysed the X-ray diffraction of other pozzolans, such as metakaolin [44] and fly ash [45].

With respect to the chemical composition, the results obtained by the X-ray fluorescence test can be seen in Table 2. It is possible to observe that the HTOSPW is a silico-aluminous material, characteristic of pozzolanic materials. Among the silica fume, fly ash and metakaolin, which are well-studied pozzolans, the HTOSPW presented a chemical composition more similar to that of metakaolin $[9,46]$ and fly ash $[47,48]$ when compared the contents of silica $\left(\mathrm{SiO}_{2}\right)$ and alumina $\left(\mathrm{Al}_{2} \mathrm{O}_{3}\right)$. Conversely, the silica fume presents a higher content of silica, reaching nearly $95 \%$ of its chemical composition [8, 9].

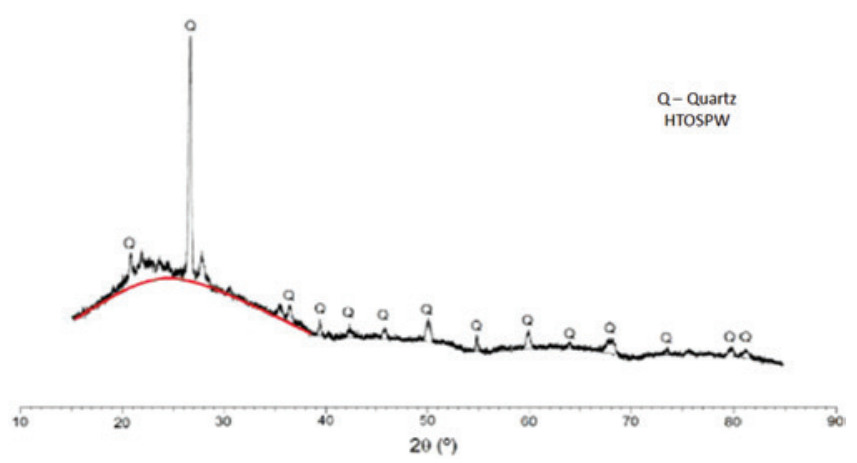

Figure 4

X-ray diffraction of HTOSPW 


\section{Table 4}

Chemical requirements established by NBR 12653-15

\begin{tabular}{ccccc}
\hline \multirow{2}{*}{ Properties } & \multicolumn{2}{c}{ Limit values for each class of pozzolanic material } & HTOSPW results (\%) \\
\cline { 2 - 4 } & $\mathbf{N}$ & $\mathbf{C}$ & $\mathbf{E}$ & \\
$\mathrm{SiO}_{2}+\mathrm{Al}_{2} \mathrm{O}_{3}+\mathrm{Fe}_{2} \mathrm{O}_{3}$ & $\geq 70$ & $\geq 70$ & $\leq 50$ & 92 \\
$\mathrm{SO}_{3}$ & $\leq 4$ & $\leq 5$ & $\leq 5$ & 0.05 \\
Moisture content & $\leq 3$ & $\leq 3$ & $\leq 3$ & 0.0 \\
Loss on ignition & $\leq 10$ & $\leq 6$ & $\leq 6$ & 0.1 \\
Available alkalis in $\mathrm{Na}_{2} \mathrm{O}_{\mathrm{eq}}{ }^{*}$ & $\leq 1.5$ & $\leq 1.5$ & $\leq 1.5$ & 2.21 \\
${ }^{*} \mathrm{Na}_{2} \mathrm{O}_{\mathrm{eq}}=\mathrm{Na}_{2} \mathrm{O}+0.658 \mathrm{~K}_{2} \mathrm{O}$ & & &
\end{tabular}

In Table 2, it can be observed the chemical composition of the OSPW, performed by Uliana et al. [26] and used in the present study. Comparing the OSPW with the HTOSPW, it is noted that the latter presents a significant increase in the alumina $\left(\mathrm{Al}_{2} \mathrm{O}_{3}\right)$ content, due to the heat treatment, indicating a pozzolanic potential higher for HTOSPW in comparison to OSPW, since the alumina is highly reactive [49].

NBR 12653 [28] establishes as chemical criteria the limits presented in Table 4. According to the pozzolans classification of this standard, the HTOSPW is considered a pozzolan class N. It can be noted that the heat treated waste met all the chemical requirements, except for the criterion of available alkalis in $\mathrm{Na}_{2} \mathrm{O}_{\text {eq }}$, which was $47 \%$ higher than the maximum allowed. The alkali percentage is not directly related to the pozzolanic activity of the material. It is associated to the alkali-silica reaction which can be developed by the contact with the reactive silica present in the aggregates, being necessary to perform tests to demonstrate the real influence of the HTOSPW in causing the alkali-silica reaction. It can be verified in different studies of other pozzolans that the values for $\mathrm{Na}_{2} \mathrm{O}_{\text {eq }}$ were higher than $1.5 \%$ for pozzolans such as fly ash [1-3].

The HTOSPW met all the physical criteria established by the standard, besides being a silico-aluminous material and presenting an amorphous appearance in the X-ray diffraction, which are basic characteristics of a pozzolanic material. Nevertheless, this characteristics do not guarantee that the material possess a pozzola-

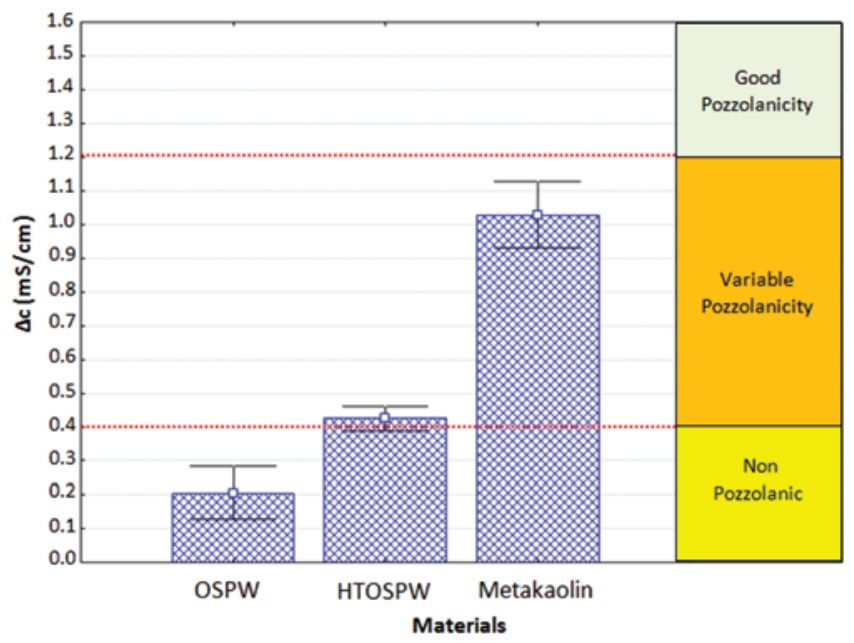

Figure 5

Pozzolanic activity test by the method of Luxán nic activity. For the pozzolanic activity, the result obtained by the method of Luxán [27] is exposed in Figure 5.

It is possible to state that the heat treatment provided an increase in the pozzolanic activity index by the method of Luxán [27], allowing the material to be classified now as of varying pozzolanicity, instead of non-pozzolanic as before the heat treatment. Vazzoler [50] also performed this test for the HTOSPW, finding the average value of $0.55 \mathrm{mS} / \mathrm{cm}$, classifying the HTOSPW as a material of varying pozzolanicity, as the one presented in this study.

Related to the metakaolin, due to be a known pozzolanic material, it was expected a higher value of conductivity variation. Kieling [42] tested the silica fume, which is also a pozzolanic material, by using the method of Luxán [27], and found the variation conductivity to be of $0.89 \mathrm{mS} / \mathrm{cm}$. Thus, it can be concluded that the classification of the HTOSPW as of varying pozzolanicity $(0.4$ to $1.2 \mathrm{mS} / \mathrm{cm})$ is a substantial result, since pozzolans as the silica fume and metakaolin also presented values within this range.

Regarding the HTOSPW performance used for lime mortar production, the procedures recommended from NBR 5751 [32] were followed, which establishes that the mortar contains normal sand, lime, pozzolan and water, with a minimum compressive strength of $6 \mathrm{MPa}$ for the material to be considered as a pozzolan. In Figure 6 are presented the results obtained, being that the average compressive strength was $7.24 \mathrm{MPa}$, a value $20.67 \%$ superior to the limit of $6 \mathrm{MPa}$, classifying the material as a pozzolan. Thus,

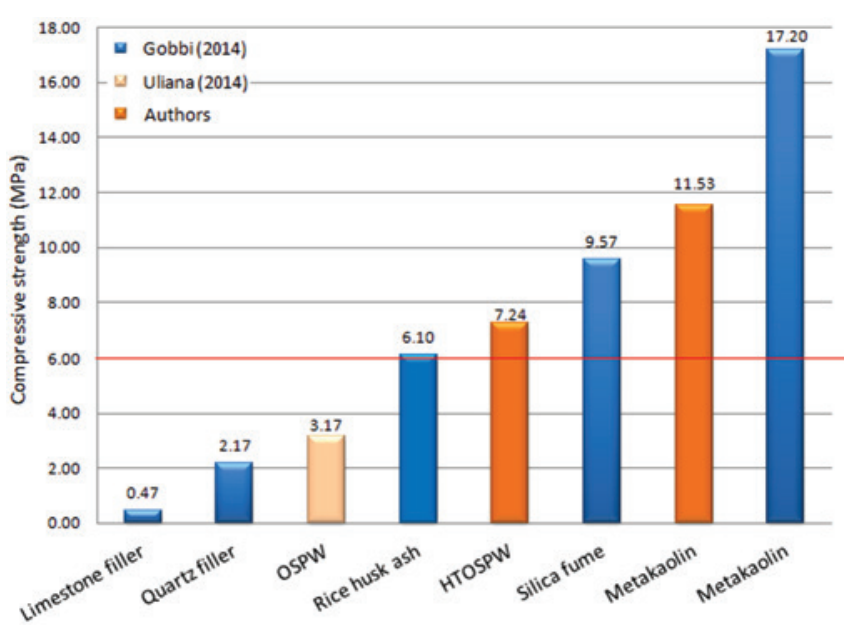

Figure 6

Pozzolanic activity test in lime mortar 
according to this criterion, the OSPW, after heat treatment, can be considered a pozzolanic material. Gobbi [51] studies the pozzolanic activity with lime for different mineral additions with the aim of analyzing the effectiveness of this method, and Uliana et al. [26] assessed the pozzolanic activity with lime of the OSPW without heat treatment. For comparison purposes, it was built the graph presented in Figure 6, which shows the results from Gobbi [51] and Uliana et al. [26] together with the ones obtained in this study. As occurred in the pozzolanic activity test by the method of Luxán [27] (Figure 5), it is possible to observe in Figure 6 an increase higher than $100 \%$ for the result obtained for HTOSPW when compared to OSPW. By comparing the physical and chemical characteristics of OSPW and HTOSPW presented in Table 2, it can be verified that, even after the heat treatment at $1200^{\circ} \mathrm{C}$, the chemical composition remained similar between the materials, and that the HTOSPW fineness, after the milling process, was also proximate to the OSPW fineness, with Blaine values of $6179 \mathrm{~cm}^{2} / \mathrm{g}$ for the latter and $6890 \mathrm{~cm}^{2} / \mathrm{g}$ for the former. Thus, it is noted that the HTOSPW capacity of reacting with the calcium hydroxide is not exclusively dependent of the chemical composition and fineness of the material. It also depend of its mineralogical structure, which after heat treatment presented an amorphous halo, as can be seen in Figure 4, different from what occurred with the OSPW without heat treatment, which presented the typical characteristic of crystalline compounds (non-amorphous) chemically stables and with low reactivity, confirming the absence of pozzolanic activity [35]. It is concluded that the compressive strength gain of the lime mortar with HTOSPW, when compared to the OSPW, is due to the modification of the crystalline structure due to the heat treatment, producing a more reactive material when compared to the OSPW.

In Figure 6 it is also possible to verify that the HTOSPW was placed between two widely studied pozzolans, with proven pozzolanic potential, being the rice husk ash and silica fume. As occurred in the method of Luxán [27], the metakaolin presented the best result for pozzolanic activity when compared to OSPW and HTOSPW.

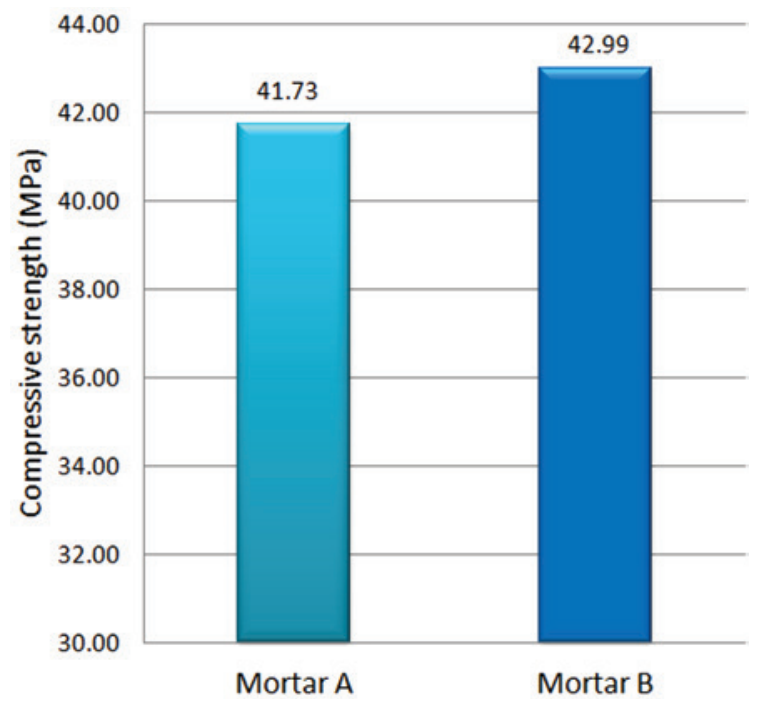

Figure 7

Pozzolanic activity test in cement mortar
With regard to the performance of the cement mortars, to be considered a pozzolan, the NBR 12653 [28] recommends that the mortar B (which replaces $25 \%$ of cement by HTOSPW, by mass) attain at least $90 \%$ of the strength obtained in mortar A (control mixture). Replacing the cement by HTOSPW in $25 \%$ content, the performance index obtained was $103 \%$, that is, the result presented $13 \%$ more than the minimum required to be considered a pozzolan (90\%). In Figure 7, it can be seen the results obtained for the mortars $\mathrm{A}$ and $\mathrm{B}$.

\subsection{Test results of the mixtures}

With regard to the concrete fresh state, it can be observed in Figure 8 that the HTOSPW addition provided a reduction of slump value. This is due to the fact that the HTOSPW is a very fine material, which would require an increase of water consumption or the use of admixture to retain the same slump of the control mixture. Neville and Brooks [52] state that the very fine particles require more water due to its high specific surface area. Mehta and Monteiro [31] affirm that, for a determined concrete workability, the use of materials with high specific surface area (fine materials), as the rice husk ash and silica fume, the demand for water increases in the mixture.

In Figure 8 , it is observed that the concrete with w/c ratio of 0.4 was the most affected by the addition, causing a reduction of $28.57 \%$ in the slump value for the concrete with $5 \%$ addition and $54.29 \%$ for the concrete with $10 \%$ addition; whereas the slump for the mixtures with w/c of 0.6 , the reductions were 15.25 and $38.90 \%$ for the content additions of 5 and $10 \%$, respectively. This was expected, since the concrete with $\mathrm{w} / \mathrm{c}$ of 0.4 had a higher quantity in mass of waste addition, since the addition was done in relation to the cement mass. In Table 3, it is verified that the concretes with w/c of 0.4 presented a cement consumption approximately $70 \%$ higher than those with $\mathrm{w} / \mathrm{c}$ of 0.6 ; thus, receiving a greater quantity of HTOSPW addition.

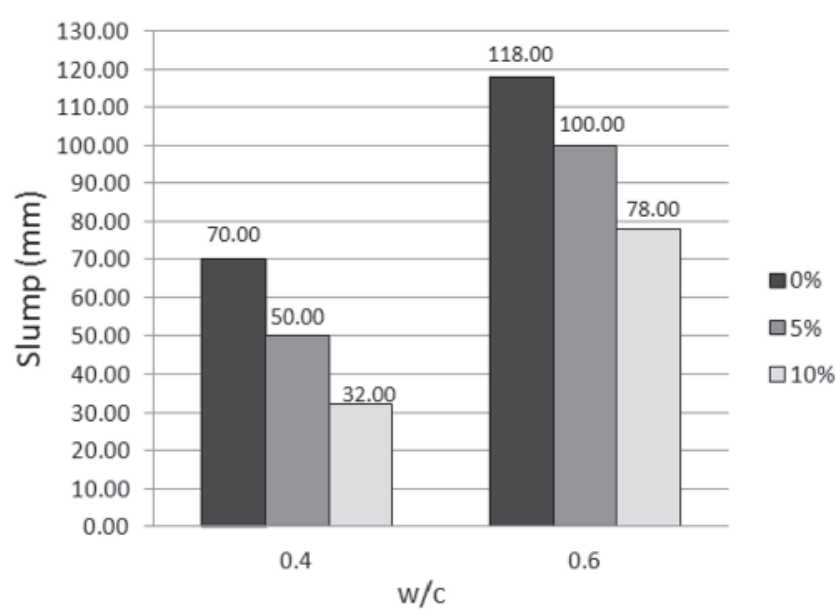

Figure 8

Slump of different types of mixes 


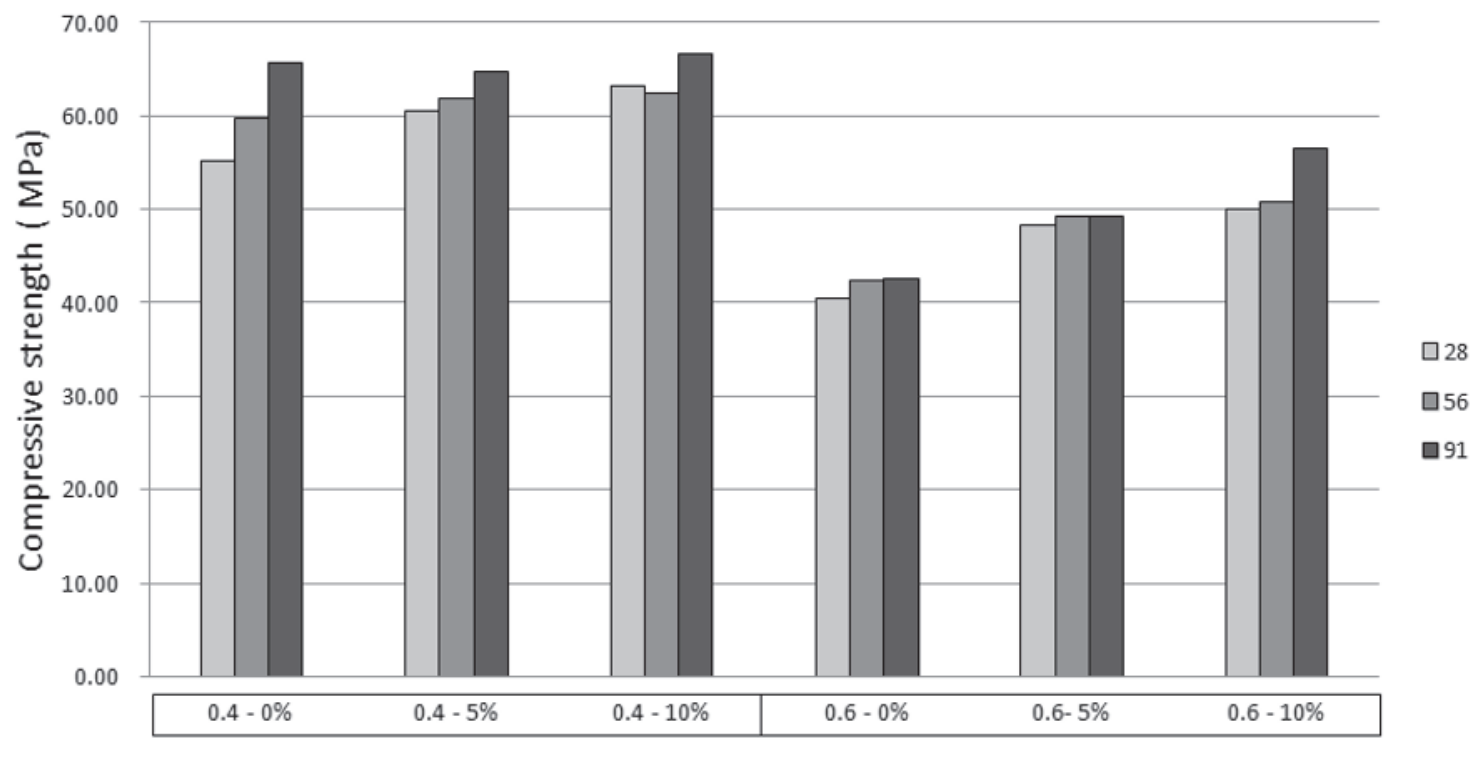

Type of mixtures

\section{Figure 9}

Compressive strength test results

\section{Table 5}

Analysis of variance of the compressive strength test results

\begin{tabular}{ccccccc}
\hline Factors & SS & DF & MS & F & p-value & Results \\
\hline w/c & 4374.8 & 1 & 4374.8 & 1860.8 & 0.000000 & Significant \\
age & 311.9 & 2 & 156.0 & 66.3 & 0.000000 & Significant \\
\% addition & 749.6 & 2 & 374.8 & 159.4 & 0.000000 & Significant \\
w/c - age & 31.3 & 2 & 15.7 & 6.7 & 0.002316 & Significant \\
w/c - \% addition & 178.1 & 2 & 89.1 & 37.9 & 0.000000 & Significant \\
age - \% addition & 55.4 & 4 & 13.9 & 5.9 & 0.000405 & Significant \\
w/c- age - \% addition & 78.7 & 4 & 19.7 & 8.4 & 0.000016 & Significant \\
\hline
\end{tabular}

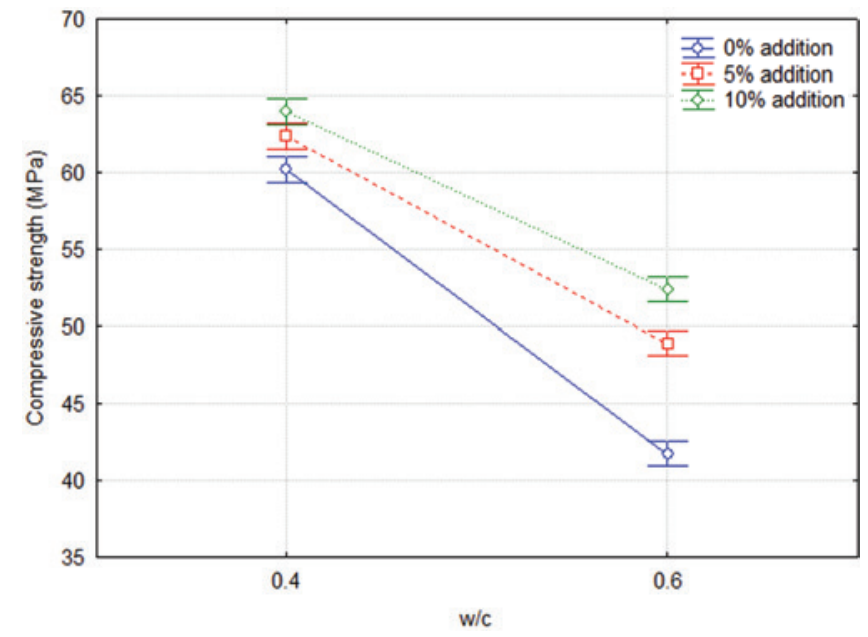

\section{Figure 10}

Influence of the interaction between $\mathrm{w} / \mathrm{c}$ ratio and addition content on the compressive strength
Regarding the compressive strength test, Figure 9 presents the average results of the analysed concrete mixtures.

In Figure 9 is possible to note that all the variables (addition, w/c ratio and age) apparently influenced the compressive strength of the mixtures. To assess the real influence of these variables, the results were submitted to the Analysis of Variance (ANOVA), which can be seen in Table 5. From this analysis, it can be concluded that all the variables indeed had an impact on the compressive strength of concretes, as well as the interaction between the variables.

For the present study, the most important analysis is the influence of HTOSPW addition content on the concrete mechanical strength. In Figure 10, it is possible to observe the interaction between the $w / c$ ratio and the addition content on compressive strength.

It is possible to conclude, from Figure 10, that in both w/c ratios studied ( 0.4 and 0.6 ), the HTOSPW addition provided an increase in the concrete compressive strength. Nevertheless, it is verified that the concretes with w/c of 0.6 presented a higher increase of strength due to the addition, presenting gains of 17.19 and $25.29 \%$ for the addition contents of 5 and $10 \%$, respectively, whereas the 


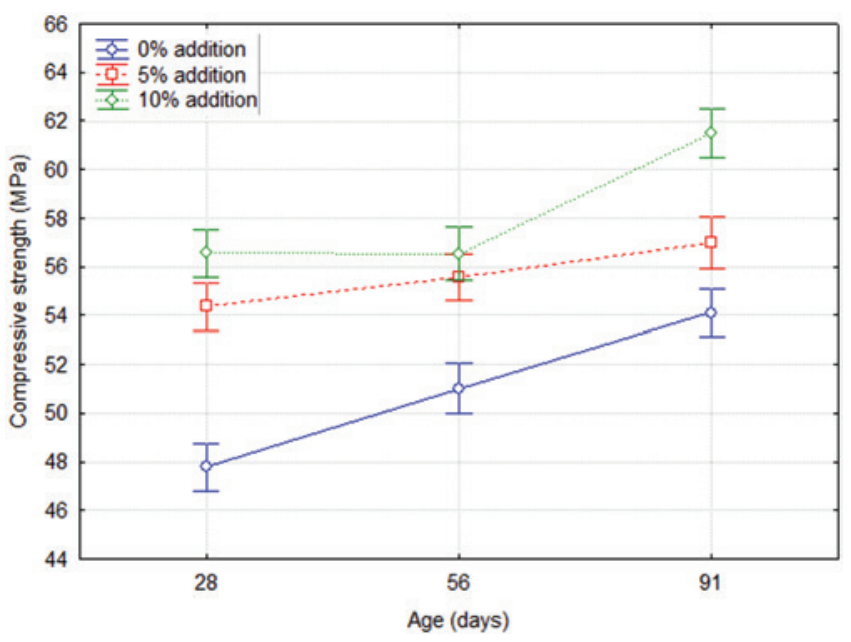

\section{Figure 11}

Influence of the interaction between age and addition content on the compressive strength

mixtures with w/c of 0.4 presented an improvement of 3.58 and $6.27 \%$, in relation to the control mixture.

One of the pozzolanic activity effects is the pore refinement of the concretes through the reaction of the pozzolan with the alkaline compounds of the paste. Probably, the concretes with w/c of 0.6 presented a higher strength increase due to being more porous when compared to the mixtures with w/c of 0.4 ; the latter being already with an increased level of pore refinement.

The influence of the interaction between the addition content and the age on the concrete compressive strength can be seen in Figure 11 It is verified that at the age of 28 days, the concretes with 5 and $10 \%$ addition presented a compressive strength superior to the control mixture, presenting the increase of 13.79 and $18.36 \%$, respectively. According to Mehta and Monteiro [31], cements containing pozzolans present a delayed increase of compressive strength if compared to the cements containing just clinker and gypsum, showing an increase due to the pozzolan only after 7 days. Thus, at 28 days it was expected a significant effect of the addition on the compressive strength. The strength increase at 28 days occurs because the $\mathrm{C}_{3} \mathrm{~S}$ (alite) has already developed most of it hydration reaction at this age; being this compound the main responsible for the compressive strength gain of concrete in the first four weeks and for the formation of $\mathrm{Ca}(\mathrm{OH})_{2}$ [52]. Thereby, besides contributing to the compressive strength increase by producing the calcium silicate hydrate (C-S-H), the alite also contributes to the formation of enough $\mathrm{Ca}(\mathrm{OH})_{2}$ to react with the pozzolan (HTOSPW), producing more $\mathrm{C}-\mathrm{S}-\mathrm{H}$, thus, causing a strength increase.

At 56 days, the addition content of $5 \%$ provided a gain in compressive strength of $8.9 \%$, whereas the $10 \%$ content caused a $10.83 \%$ increase when compared to the control mixture. At this age, it was expected a higher increase in compressive strength for both addition contents; however, in fact, similar strength results to the ones verified at 28 days were observed. It is possible that in this time interval (28-56 days) most of the $\mathrm{C}_{3} \mathrm{~S}$ hydration process has already occurred; thus, not producing additional $\mathrm{Ca}(\mathrm{OH})_{2}$ to react with the remaining $\mathrm{HTOSPW}$, explaining the low compressive strength increase from 28 to 56 days.
At 91 days, it is verified that the $5 \%$ addition provided a $5.30 \%$ compressive strength gain, whereas the $10 \%$ addition caused a $13.64 \%$ increase when compared to the control mixture. It is noted in Figure 11 that the compressive strength gain with $10 \%$ addition between the 56 and 91 days interval was superior to that between 28 and 56 days. This is possibly justified because the $C_{2} S$ (belite) - the cement compound most responsible for the compressive strength gain after 4 weeks hydration [52] - provided a new quantity of $\mathrm{Ca}(\mathrm{OH})_{2}$, capable of combining with the remaining HTOSPW and forming more C-S-H. This effect was more prominent for the $10 \%$ addition since it has a greater quantity of HTOSPW, whereas the $5 \%$ addition must have reacted almost completely with the $\mathrm{C}_{3} \mathrm{~S}$ within the first four weeks.

Lastly, it can be noted in Figure 12 the isolated influence of addition content on compressive strength of concretes. This represents a global analysis, that is, each data point in this graph represents an average of the concrete results, for all ages and w/c ratios considered. It can be observed that the $5 \%$ addition provided an increase of compressive strength of $9.15 \%$, whereas the $10 \%$ content caused a $14.18 \%$ gain. Therefore, it is concluded that both addition contents were beneficial for the concrete mixtures, providing a significant increase in compressive strength, caused probably by the pozzolanic activity of the HTOSPW, which by reacting with the cement hydration compounds - mainly the $\mathrm{Ca}(\mathrm{OH})_{2}$ - formed C$\mathrm{S}-\mathrm{H}$, providing a pore refinement; thus, improving the mechanical properties of the concrete.

\section{Conclusions}

- The HTOSPW was characterized as a fine material, silico-aluminous and presenting amorphous phase in its atomic structure, characteristic of pozzolanic materials. The HTOSPW met the criteria of pozzolanic material for the method of Luxán [27] and the physical requirement of the NBR 12653 [28]. Regarding the chemical requirements established by the NBR 12653 [28], the only criterion not fulfilled was the maximum limit of $\mathrm{Na}_{2} \mathrm{O}_{\text {eq }}$, which do not have a direct relation to the pozzolanic activity of the material, being related to the possible alkali-silica

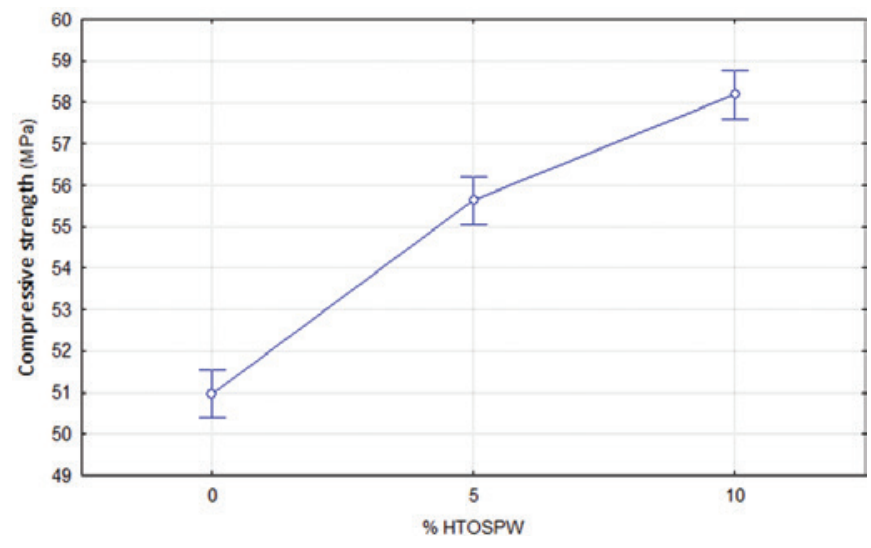

Figure 12

Isolated effect of the HTOSPW addition content influence on compressive strength 
reaction that the pozzolan can develop; being that some commercial pozzolans also did not met this criterion, as the fly ash [1-3]. Thus, it can be concluded that the HTOSPW is a pozzolanic material, requiring future studies to assess the alkali-silica reaction that it may possibly develop.

- Regarding the production of concretes using the HTOSPW, in the fresh state, a fluidity reduction was observed with the increase of addition content - an expected trend in concretes which have the addition of fine materials. At the hardened state, it was possible to verify a significant increase in compressive strength due to the addition content, that is, both contents ( 5 and $10 \%$ ) were beneficial for the compressive strength of the analyzed mixtures. As the highest content of $10 \%$ provided an increase of strength compared to the others, it is possible that increased addition contents also provide a compressive strength gain; thus, future studies may evaluate the increase of addition, or the cement partial replacement by HTOSPW.

\section{Acknowledgements}

The authors acknowledge the support of the companies Concrevit for donating the sand and the Lafarge/Holcim for donating the cement CPV-ARI. Specially, the authors wish to thank the technician Raimundo, from Lafarge/Holcim, for the availability in realizing the Blaine fineness test in the HTOSPW. It is also acknowledge the responsible for the ceramic materials laboratory of the IFES - Vitória Campus - which performed the laser particle size analysis on the HTOSPW. Also, it would not be possible the development of this research without the financial support from CAPES - Coordination for the Improvement of Higher Education Personnel, from the Brazilian government.

\section{References}

[1] VEGAS, I.; GAITERO, J. J.; URRETA, J.; GARCÍA, R.; FRÍAS, M. Aging and durability of ternary cements containing fly ash and activated paper sludge. Construction and Building Materials 52 (2014) 253-260.

[2] RIVERA, F.; MARTÍNEZ, P.; CASTRO, J.; LÓPEZ, M. Massive volume fly-ash concrete: A more sustainable material with fly ash replacing cement and aggregates. Cement and Concrete Composites 63 (2015) 104-112.

[3] CELIK, K.; MERAL, C.; GURSEL, A. P.; MEHTA, P. K.; HORVATH, A.; MONTEIRO, P. J. M. Mechanical properties, durability, and life-cycle assessment of self-consolidating concrete mixtures made with blended portland cements containing fly ash and limestone powder. Cement \& Concrete Composites 56 (2015) 59-72.

[4] SHAIKH, F. U. A.; SUPIT, S. W. M. Compressive strength and durability properties of high volume fly ash (HVFA) concretes containing ultrafine fly ash (UFFA). Construction and Building Materials 82 (2015) 192-205.

[5] WANG, X. -Y.; PARK, K. -B. Analysis of compressive strength development of concrete containing high volume fly ash. Construction and Building Materials 98 (2015) 810-819.

[6] JALAL, M.; POULADKHAN, A.; HARANDI, O. F.; JAFARI, D. Comparative study on effects of Class $F$ fly ash, nano silica and sílica fume on properties of high performance self compacting concrete. Construction and Building Materials 94 (2015) 90-104.

[7] ZHANG, Z.; ZHANG, B.; YAN, P. Comparative study of effect of raw and densified silica fume in the paste, mortar and concrete. Construction and Building Materials 105 (2016) 82-93.

[8] HOFFMANN, A. T. Influência da adição de sílica ativa, relação água/aglomerante, temperatura e tempo de cura no coeficiente de difusão de cloretos em concretos. Dissertation (Master's Degree). Universidade Federal do Rio Grande do Sul - Porto Alegre (2001).

[9] DUAN, P.; SHUI, Z.; CHEN, W.; SHEN, C. Effects of metakaolin, silica fume and slag on pore structure, interfacial transition zone and compressive strength of concrete. Construction and Building Materials 44 (2013) 1-6.

[10] DONATELLO, S.; TYRER, M.; CHEESEMAN, C. R. Comparison of test methods to assess pozzolanic activity. Cement e Concrete Composites 32 (2010) 121-127.

[11] MASHALY, A. O.; EL-KALIOUBY, B. A.; SHALABY, B. N.; EL-GOHARY, A. M.; RASHWAN, M. A. Effects of marble sludge incorporation on the properties of cement composites and concrete paving blocks. Journal of Cleaner Production 112 (2016) 731-741.

[12] RAMOS, T.; MATOS, A. M.; SCHMIDT, B.; RIO, J.; SOUSACOUTINHO, J. Granitic quarry sludge waste in mortar: Effect on strength and durability. Construction and Building Materials 47 (2013) 101-109.

[13] SADEK, D. M.; EL-ATTAR, M. M.; ALI, H. A. Reusing of marble and granite powders in self-compacting concrete for sustainable development. Journal of Cleaner Production 121 (2016) 19-32.

[14] CORINALDESI, V.; MORICONI, G.; NAIK, T. R. Characterization of marble powder for its use in mortar and concrete. Construction and Building Materials 24 (2010) 113-117.

[15] ACCHAR, W.; VIEIRA, F. A.; HOTZA, D. Effect of marble and granite sludge in clay materials. Materials Science and Engineering A 419 (2006) 306-309.

[16] MENEZES, R. R.; FERREIRA, H. S.; NEVES, G. A.; LIRA, H. L.; FERREIRA, H. C. Use of granite sawing wastes in the production of ceramic bricks and tiles. Journal of the European Ceramic Society 25 (2005) 1149-1158.

[17] SABOYA Jr., F.; XAVIER, G. C.; ALEXANDRE, J. The use of the powder marble by-product to enhance the properties of brick ceramic. Construction and Building Materials 21 (2007) 1950-1960.

[18] P. TORRES, P.; FERNANDES, H. R.; AGATHOPOULOS, S.; TULYAGANOV, D. U.; FERREIRA, J. M. F. Incorporation of granite cutting sludge in industrial porcelain tile formulations. Journal of the European Ceramic Society 24 (2004) 3177-3185.

[19] AKBULUT, H.; GÜRER, C.; ÇETIN, S.; ELMACI, A. Investigation of using granite sludge as filler in bituminous hot mixtures. Construction and Building Materials 36 (2012) 430-436.

[20] AKBULUT, H.; GÜRER, C. Use of aggregates produced from marble quarry waste in asphalt pavements. Building and Environment 42 (2007) 1921-1930. 
[21] KARASAHIN, M.; TERZI, S. Evaluation of marble waste dust in the mixture of asphaltic concrete. Construction and Building Materials 21 (2007) 616-620.

[22] DEPARTAMENTO NACIONAL DE PRODUÇÃO MINERAL - DNPM. Sumário Mineral 2014. Brasília, DF: 2014. Available at: <http://www.dnpm.gov.br/dnpm/sumarios/rochasornamentais-de-revestimento-sumario-mineral-2014/view> Accessed on: 7 jul. 2016.

[23] BACARJI, E. D.; TOLEDO FILHO, R.; KOENDERS, E. A. B.; FIGUEIREDO, E. P.; LOPES, J. L. M. P. Sustainability perspective of marble and granite residues as concrete Fillers. Construction and Building Materials 45 (2013) 1-10.

[24] AL-AKHRAS, N. M.; ABABNEH, A.; ALARAJI W, A. Using burnt stone slurry in mortar mixes. Construction and Building Materials. 2010.

[25] MÁRMOL, I.; BALLESTER, P.; CERRO, S.; MONRÓS, G.; MORALES, J.; SÁNCHEZ, L. Use of granite sludge wastes for the production of coloured cement-based mortars. Cement and Concrete Composites. (2010).

[26] ULIANA, J. G.; CALMON, J. L.; VIEIRA, G. L.; TEIXEIRA, J. E. S. L.; NUNES, E. Heat treatment of processing sludge of ornamental rocks: application as pozzolan in cement matrices. Ibracon Structures and materials journal. v. 8 n. 2 (2015) 100-123.

[27] LUXÁN, M. P.; MADRUGA, F.; SAAVEDRA, J. Rapid evaluation of pozzolanic activity of natural products by conductivity measurement. Cement and Concrete Research. (1989).

[28] ASSOCIAÇÃO BRASILEIRA DE NORMAS TÉCNICAS. NBR 12653 - Materiais Pozolânicos - Especificação. Rio de Janeiro, 2015.

[29] ASSOCIAÇÃO BRASILEIRA DE NORMAS TÉCNICAS. NBR 15894-3: Metacaulim para uso com Cimento Portland em concreto, argamassa e pasta: determinação da Finura por Meio da Peneira 45 $\mu \mathrm{m}$. Rio de Janeiro, 2010.

[30] ASSOCIAÇÃO BRASILEIRA DE NORMAS TÉCNICAS. NBR 11579 - Cimento Portland: determinação do índice de finura por meio da peneira $75 \mu \mathrm{m}\left(\mathrm{n}^{\circ} 200\right)$. Rio de Janeiro, 2013.

[31] MEHTA, P. K.; MONTEIRO, P. J. M. Concreto: microestrutura, propriedades e materiais. 3 ed. São Paulo: PINI, 2008.

[32] ASSOCIAÇÃO BRASILEIRA DE NORMAS TÉCNICAS. NBR 5751 - Materiais pozolânicos: determinação da atividade pozolânica com cal aos sete dias. Rio de Janeiro, 2015.

[33] ASSOCIAÇÃO BRASILEIRA DE NORMAS TÉCNICAS. NBR 5752 - Materiais pozolânicos: determinação do índice de desempenho com cimento Portland aos 28 dias. Rio de Janeiro, 2014.

[34] HELENE, P.; TERZIAN, P. Manual de dosagem e controle do concreto. Pini; Brasília: SENAI, 1992.

[35] SOARES, R. B. Contribuição ao estudo da durabilidade de concretos produzidos com a incorporação de resíduo do beneficiamento de rochas ornamentais. 2014. 163 f. Dissertation (Master in Civil Engineering) - Graduate Program of Civil Engineering, Universidade Federal do Espírito Santo, Vitória, 2014.

[36] DIETRICH, Y. P. Durabilidade de concretos produzidos com adição de resíduos provenientes de rochas ornamentais frente à ação de íons cloreto. 2015. 181f. Dissertation (Master in Civil Engineering) - Graduate Program of Civil Engineering, Universidade Federal do Espírito Santo, Vitória, 2015.

[37] DEGEN, M. K.; VIEIRA, G. L.; CALMON, J.; L. ULIANA, J. G.; BASTOS, R. S. Concretos produzidos com resíduos provenientes do beneficiamento de rochas ornamentais como substituto parcial de cimento. Congresso Brasileiro do Concreto, 55. 2013, Gramado. Proceedings. Gramado: IBRACON, 2013.

[38] ASSOCIAÇÃO BRASILEIRA DE NORMAS TÉCNICAS. NBR NM 67: Concreto: determinação da consistência pelo abatimento do tronco de cone. Rio de Janeiro, 1998.

[39] SIRIRUANG, C.; TOOCHINDA, P.; JULNIPITAWONG, P.; TANGTERMSIRIKUL, S. $\mathrm{CO}_{2}$ capture using fly ash from coal fired power plant and applications of $\mathrm{CO}_{2}$-captured fly ash as a mineral admixture for concrete. Journal of Environmental Management 170 (2016) 70-78.

[40] YOSHITAKE, I.; UENO, S.; USHIO, Y.; ARANO, H.; FUKUMOTO, S. Abrasion and skid resistance of recyclable fly ash concrete pavement made with limestone aggregate. Construction and Building Materials 112 (2016) 440-446.

[41] AHN, Y. B.; JANG, J. G.; LEE, H. K. Mechanical properties of lightweight concrete made with coal ashes after exposure to elevated temperatures. Cement and Concrete Composites 72 (2016) 27-38.

[42] KIELING, A. G. Influência da segregação no desempenho de cinzas de casca de arroz como pozolana e material adsorvente. Dissertation (Master's Degree). Universidade do Vale do Rio dos Sinos. São Leopoldo. 2009.

[43] INTERNATIONAL LABOR ORGANIZATION. International chemical safety card on crystalline silica, 2010. Available at: <http://www.ilo.org/dyn/icsc/showcard.display?p_card_ id=0808>. Accessed on: 18 sep. 2015.

[44] MELO, C. R.; RIELLA, H. G. Síntese de zeólita tipo NaA a partir de caulim para obtenção de zeólita $5 \mathrm{~A}$ através de troca iônica. Cerâmica 56 (2010) 340-346.

[45] VARGAS, A. S.; DAL MOLIN, D. C. C.; VILELA, A. C. F.; JALALI, S.; GOMES, J. C. Cinzas volantes álcali-ativadas com solução combinada de $\mathrm{NaOH}$ e $\mathrm{Ca}(\mathrm{OH})_{2}$. Revista Matéria, v. 12, n. 3, pp. 462-469, 2007.

[46] ISMAIL, M. K.; HASSAN, A. A. A. Use of metakaolin on enhancing the mechanical properties of self-consolidating concrete containing high percentages of crumb rubber. Journal of Cleaner Production 125 (2016) 282-295.

[47] SHAIKH, F. U. A.; SUPIT, S. W. M. Mechanical and durability properties of high volume fly ash (HVFA) concrete containing calcium carbonate $\left(\mathrm{CaCO}_{3}\right)$ nanoparticles. Construction and Building Materials 70 (2014) 309-321.

[48] APONTE, D. F.; BARRA, M.; VÀZQUEZ, E. Durability and cementing efficiency of fly ash in concretes. Construction and Building Materials 30 (2012) 537-546.

[49] PAIVA, H.; SILVA, A. S.; VELOSA, A.; CACHIM, P.; FERREIRA, V.M. Microstructure and hardened state properties on pozzolan-containign concrete. Construction and Building Materials 140 (2017) 374-384.

[50] VAZZOLER, J. S. Investigação de potencialidade pozolânica 
do resíduo de beneficiamento de rochas ornamentais após tratamento térmico para produção de pasta cimentícia. Vitória, 2015. Dissertation (Master in Civil Engineering) Graduate Program of Civil Engineering, Universidade Federal do Espírito Santo, 2015.

[51] GOBBI, A. Atividade pozolânica de adições minerais pelas NBR 5751/2012 e NBR 5752/2012: uma análise crítica a partir de métodos complementares. Dissertation (Master's Degree) Universidade Federal do Paraná. Paraná. 2014.

[52] NEVILLE, A.; M. BROOKS J. J. Tecnologia do concreto. 2. ed. Porto Alegre: Bookman, 2013. 448p. 